\title{
Diseases of medicinal and aromatic plants: Insights in nematode biomanagement ${ }^{*}$
}

\author{
RAKESH PANDEY \\ Microbial Technology and Nematology Department, CSIR-Central Institute of Medicinal and Aromatic \\ Plants, Lucknow 226 015, Uttar Pradesh, India
}

Received: 3 February 2017/ Accepted: 20 February 2017/ Published online: 23 March 2017 (c) Indian Phytopathological Society 2017

Keywords: Aswagandha, management, Meloidogyne spp., mint, nematode, patchouli

\section{SUMMARY}

The cultivation of medicinal and aromatic plants (MAPs) has considerably increased in tropical and sub tropical countries of the world to meet the requirement of pharmaceutical, perfumery, cosmetic and food industries. Unfortunately, the major source of raw materials are highly susceptible to many diseases caused by variety of pest and pathogens viz. fungi, bacteria, viruses, phytoplasmas, insects and nematodes, which are responsible for severe loss in crop production/ yield and also affecting loss of major genetic resource of MAPs too. Therefore, the disease caused by such pest and pathogen is a major limiting factor for the successful cultivation of major medicinal and aromatic plants. Although, chemical control of plant diseases has proved effective but it cannot be recommended to the farmers due to its high cost and adverse impact on non target organism, human, animal and environmental health. Due to enormous use of medicinal plants in herbal medicines, maximum care is the need of the hours to manage diseases of MAPs. Some of the other alternatives for disease management are available in medicinal and aromatic plants like resistant germplasm, useful organic materials, effective biocontrol agents and other cultural/ physical method. Such resistant and tolerant germplasm could be exploited in future plant breeding programmes for developing resistant/ tolerant genotypes against major pest and pathogens. Various organic materials are available which have been proven useful to decrease disease incidence and enhanced MAPs yield and which could also be used in ongoing programmes for better and healthy plants. Large numbers of bio agents are available which could also be used on large scale to

*J.F. Dastur Memorial Award Lecture delivered at $69^{\text {th }}$ Annual Meeting of Indian Phytopathological Society and National Symposium on "Diagnosis of and management of plant diseases: Integrated approaches and recent trends". January 9-11, 2017 at ICAR Complex for NEH Region, Umiam, Shillong, Meghalaya

Email: r.pandey@ cimap.res.in, rakeshpandey66@ hotmail.com protect MAPs against various pest and pathogens. However, much attention is needed to study and develop a new strategy to mange major diseases in an ecofriendly way, which should be cost effective and environmentally friendly.

The availability of nutritious and healthy food, disease controlling food supplements and therapeutics are, among several factors, the determinants of quality of human life. In recent years, traditional medicines derived from plant sources are one of the important ways to support herbal medicine system for human health care. For example in China about $40 \%$ of total medicine consumption is attributed to traditional tribal medicine. The herbal medicine demand in Japan and other developed nations is very high. Similarly, aroma compounds from botanical sources are being increasingly used in cosmeceutical, nutraceutical, food and flavour industries due to the growing awareness in common masses about the risks involved in synthetic components in parallel products. The plant retail market including herbs and medicinal plants in the US are estimated to be approximately US\$ 1.6 billion annually. The prima facie importance of MAPs can be figured out from the fact that the expected sale of herbal medicines is likely to increase up to US \$ 3 trillion by 2020 (Schippmann et al., 2002). In European countries about 400,000 ton of medicinal plant material is exported from Asia and Africa. The average market value of MAPs material is more than US\$1 billion. Therefore, it is useful to say that the major raw materials used in pharmaceutical industries come from medicinal plants globally. Of late, farmers are increasingly motivated to cultivate medicinal and aromatic plants (people in tropical and subtropical countries cultivate these crops as industrial cash crop) because these crops can be incorporated in various cropping systems and also generate significant income. The cultivation, processing and trade through value addition of materials coming from MAPs are providing much needed avenues of self 
employment. The business opportunities in the sector of medicinal plants are enormous and are visible on the rise due to the diversified uses that plant inhabited important molecules are finding in pharmaceutical, cosmeceutical, nutraceutical and agri chemical industries. In well-developed industrialised nations plant derived drug prescriptions have become a major element in maintenance of human health. Therefore, MAPs have become an integral component of research in most of the pharmaceutical, perfumery, cosmetic and nutraceutical industries. It has also been estimated that Hong Kong, Germany, Japan and Singapore are the major importing countries in medicinal plant trade with estimated share of $17.3,12.0,10.2$ and $8.4 \%$ respectively. In concrete it was found that Europe has become a huge reservoir of global herbal market, constituting about $45 \%$ of total market followed by North America (18.2\%) and Asia (18.2\%). With an increasing usage of such products, any attempt by researchers to enhance the production and yield of MAPs can be a great endeavour towards meeting the global demand.

The situation however, is not as smooth as it appears to be since MAPs production is hindered by various biotic and abiotic factors amongst which biotic constraints are more important. Till date, however, a considerable attention has been made to the diseases affecting the crop plants providing food to mankind but what has been largely ignored are the diseases affecting our own saviours MAPs (Reddy and Pandey, 2013). Studies further suggest that in the near future, threat hovers over the global food production, including MAPs as predictions expect pronounced affect on the growth and survival rates of pests and pathogens, along with the increased disease severity due to changing climatic conditions (Elad and Pertot, 2014; Pandey and Saikia, 2012). Apart from the changing climatic conditions, large scale cultivation of MAPs for meeting the huge demands of pharmaceutical and perfumery industries, in a manner has paved a way for the increased occurrence and severity of diseases. Furthermore, the cultivation of MAPs faces critical damage from diverse group of microbes (bacteria, fungi, viruses, phytoplasmas and nematodes), thereby posing serious threat to the yield, biomass, bioactive potential and future prospects of MAPs (Table 1). Overall, financial losses arising from plant diseases caused by phytopathogens not only reduces the yield of plant secondary metabolites but also the crop value which not only discourages consumers self-belief but also the prosperity of the producers. The present article specially focuses on the major diseases of MAPs, their effect on various metabolic processes of the host plants with insight consideration of plant parasitic nematodes especially root-knot nematode (Meloidogyne spp.) affecting the production and yield of MAPs and their ecofriendly biomanagement.

\section{Fungal and bacterial diseases}

Currently, commercial cultivation of MAPs has tremendously improved several folds due to increasing global demand in pharmaceutical, perfumery, cosmetic and food industries. These plants are often affected by a variety of diseases caused by fungi, bacteria, viruses and phytoplasmas of which fungal diseases are particularly important. A variety of fungi influence pathogenic invasions on MAPs and infect the aerial, foliage and underground plant parts. Amongst the various fungal diseases, powdery mildews primarily appear on the leaves and fresh stems, thereby covering the entire surface of the growing parts of plants. Similarly, rust is another airborne disease known to attack leaves, twigs, branches and fruits. They produce pustules on the upper and lower leaves surface. The other group belonging to fungal pathogens causes leaf spot and blight diseases where the symptoms appear on the leaves in the form of leaf spot followed by shrinking of the dead area and separation from the surrounding healthy tissues with varying lesion shapes (Bhandari et al., 2014; Thaung, 2008). In case of blight, burnt appearance leading to sudden death of the plant or its conspicuous parts viz. leaves, twigs or blossoms occurs (Ramappa Parashurama and Shivanna, 2013). Several other diseases of MAPs such as root rot, wilt, damping off, anthracnose and die back affects crop badly caused by fungal and bacterial pathogens. They can generally be identified by decaying tissue which may be hard, dry, spongy, watery, mushy, or slimy in appearance.

\section{Management}

The major control measures available for all these different diseases are primarily the chemical control. Treatment of terminal cuttings with carbendazim solution $\left(1 \mathrm{~g} \mathrm{~L}^{-1}\right)$ before plantation is an effective protection from fungal pathogens. Streptocyclin application (300 ppm) around the roots of transplanted cuttings protects the crop from bacterial infection (www.indg.in). Similarly, the chemical emisan $(0.2 \%)$ is effective for wilt disease treatment (Boby and Bagyaraj, 2003). Paramasivan et al. (2007) reported that the use of chemical fungicide (carbendazim) reduced the disease incidence by $18 \%$. Although chemicals are effective for the control of all these diseases, yet their association with several harmful effects has led to the arousal of the need for alternative measures. Rhizospheric microorganisms prove to be a potential source of novel natural products for exploitation in agriculture and are recognized as a promising group in terms of diversity and pharmaceutical potential (Pliego et al., 2011). The reduction of pathogen density or disease producing activities of a pathogen by one or more microorganisms, termed as biocontrol is achieved by competition, hyperparasitism, induced resistance etc. Several biocontrol agents have been successfully used and a large number of products are available in world market which are not only highly economical also ecofriendly with no adverse impact on human health.

\section{Viruses and phytoplasma}

Plant viruses and phytoplasma also cause various diseases which affects the biomass yield and production of MAPs worldwide. Large numbers of MAPs are reported to be infected by plant viruses viz. Mentha spp., 
Table 1. Major diseases on MAPs (Singh, Gupta and Pandey, 2016b)

\begin{tabular}{|c|c|}
\hline Disease & Crops \\
\hline Rust & Mentha spp. \\
\hline Downy mildew & $\begin{array}{l}\text { Papaver somniferum, } \\
\text { Ocimum basilicum, } \\
\text { Plantago ovata, Humulus } \\
\text { lupulus, Capsicum annum }\end{array}$ \\
\hline Powdery mildew & $\begin{array}{l}\text { M. arvensis, Rosa } \\
\text { damascene, Anethum } \\
\text { graveolens, Salvia } \\
\text { officinalis, H. lupulus }\end{array}$ \\
\hline $\begin{array}{l}\text { Alternaria/ } \\
\text { Ascochyta leaf spot }\end{array}$ & $\begin{array}{l}\text { Mentha spp., } \\
\text { Hyoscyamus spp., } \\
\text { O. basilicum }\end{array}$ \\
\hline $\begin{array}{l}\text { Cercospora leaf } \\
\text { spot }\end{array}$ & $\begin{array}{l}\text { Mentha spp., } \\
\text { P. somniferum, Rauvolfia } \\
\text { serpentine }\end{array}$ \\
\hline $\begin{array}{l}\text { Colletotrichum } \\
\text { leaf spot }\end{array}$ & $\begin{array}{l}\text { Abelmoschus maschatus, } \\
\text { Cymbopogan flexuosus }\end{array}$ \\
\hline $\begin{array}{l}\text { Cornyespora leaf } \\
\text { spot }\end{array}$ & $\begin{array}{l}\text { M. arvensis, } R \text {. serpentine, } \\
\text { O. basilicum }\end{array}$ \\
\hline Curvalaria leaf spot & C. flexuosus, $R$. serpentine \\
\hline $\begin{array}{l}\text { Diplocarpon black } \\
\text { spot }\end{array}$ & R. damascene \\
\hline $\begin{array}{l}\text { Drechsleral } \\
\text { Helminthosporium } \\
\text { leaf spot }\end{array}$ & $\begin{array}{l}\text { Costus speciosus, } \\
\text { C. flexuosus }\end{array}$ \\
\hline $\begin{array}{l}\text { Macrophomina } \\
\text { leaf spot }\end{array}$ & Chlorophytum borivilianum \\
\hline $\begin{array}{l}\text { Myrothecium leaf } \\
\text { spot }\end{array}$ & Withania somnifera \\
\hline Alternaria blight & $\begin{array}{l}\text { Pelargonium graveolens, } \\
\text { Pogostemon cablin, } \\
\text { Mentha spp., } \\
\text { P. somniferum, } \\
\text { W. somnifera, } \\
\text { R. serpentine, Cassia } \\
\text { angustifolia, P. ovata }\end{array}$ \\
\hline $\begin{array}{l}\text { Colletotrichum } \\
\text { blight }\end{array}$ & $\begin{array}{l}\text { O. basilicum, } \\
\text { C. borivilianum, } \\
\text { R. serpentine }\end{array}$ \\
\hline
\end{tabular}

Curvalaria leaf blight $C$. winterianus, $C$. martinii

$\begin{array}{ll}\begin{array}{l}\text { Ellisiella blight } \\ \text { Macrophomina }\end{array} & \text { C. martinii } \\ \text { blight } & \text { Rerpentine } \\ \begin{array}{ll}\text { Phytophthora blight } & \text { C. speciosus, A.maschatus, } \\ & \text { Catharanthus roseus }\end{array}\end{array}$

Rhizoctonia blight $\quad$ R. serpentine, C. forskohlii, Mentha spp.

Xanthomonas blight Hyoscyamus muticus

Anthracnose

P. graveolens, $R$. serpentine, M. piperita

\author{
Causal organism \\ Puccinia menthae \\ Peronospora arborescens, \\ P. lamii, P. alta, \\ Pseudoperonospora \\ plantaginis, P. humuli,

$$
\text { P. tabacina }
$$ \\ Erysiphe cichoracearum, \\ Sphaerotheca pannosa, \\ E. heraclei, E. cichoracearun \\ Alternaria tenuis, A. alternata, \\ Ascochyta kashmiriana \\ Cercospora menthicola, \\ C. papaveri, C. purpurea, \\ C. rauwolfiae, C. serpentinae \\ Colletotrichum graminicola, \\ C. capsici \\ C. cassiicola \\ Curvalaria verruciformi, \\ C. trifolii, C. lunata \\ Diplocarpon rosae
}

Drechslera victorie, D. holmii,

D. sacchari, Helminthosporium leucostylum, $D$. rostrata

Macrophomina phaseolina

Myrothecium roridum

A. alternata, $A$.

phragmospora, A. tenuis,

A. cassiae

C. capsici, C. gloeosporiodes

Curvalaria andropogonis,

C. eragrostides, C. trifolii

Ellisiella caudata

M. phaseolina

Phytophthora nicotianae var nicotianae, P. parasitica

Rhizoctonia solani

Xanthomonas compestris pv. turf

C. acutatum, C. gleosporiodes,

Sphaceloma menthae
Symptoms

Rust pustules on lower surface of leaf

Chlorotic to light brown nectrotic lesions on the leaves and leaves curled and twisted

Crooked stems and curled leaves. Chlorotic spots appear on the surface and brownish discolorations appear in the form of the powdery mass

Dark brown spherical spots spread over the infected leaves

Necrotic spots with dark brown margin scattered on the leaves

Reddish brown spots, holes are formed due to detachment of infected tissue

Yellowish to brown nectrotic spots with chlorotic halo over the surface of leaves

Small oval to elongated dark brown necrotic lesions

Brown to back spots with radiating dark purplish margin on the upper surface of leaves

Minute yellow, circular spots unevenly scattered over the infected leaves.

Water soaked lesions surrounded with dark brown margin and measured $3 \times 2 \mathrm{~mm}$ in size

Small, dull yellow to brown coloured water soaked spots on the leaves

Brown necrotic irregular lesions on the infected leaves. Dark brown patched surrounded with chlorotic halo

Small chlorotic spots on lower leaves. Spots enlarged rapidly, coalesced and turn to brown patches

Elongated reddish brown necrotic lesions on the leaves

Minute dark brown necrotic lesions

Necrotic lesions predominatly at the apex and along the margins of infected leaves

Dark brown spots on the leaves. Spots enlarged and coalesce together forming irregular necrotic patches.

Water soaked irregular lesions starting from the leaf margins spread inwards.

Water soaked necrotic lesion of unlimited growth.

Numerous minutenecrotic spots on the leaves which enlarge to develop into typical anthracnose lesions 


\begin{tabular}{|c|c|c|c|}
\hline Disease & Crops & Causal organism & Symptoms \\
\hline Die- back & C. roseus & C. dematium, Pythium butleri & $\begin{array}{l}\text { Withering of the terminal buds of the young } \\
\text { branches followed by wilting and drying. }\end{array}$ \\
\hline Collar rot & $\begin{array}{l}\text { P. somniferum, } \\
\text { Trachyspermum ammi, } \\
\text { C. borivilianum }\end{array}$ & $\begin{array}{l}\text { R. solani, Sclerotinia } \\
\text { sclerotiorum, Corticium rolfsii }\end{array}$ & $\begin{array}{l}\text { Chlorosis on the lower leaves with small } \\
\text { brown necrotic lesion on the collar region }\end{array}$ \\
\hline $\begin{array}{l}\text { Inflorescence \& } \\
\text { fruit rot }\end{array}$ & $\begin{array}{l}\text { R. serpentine, C. forskohlii, } \\
\text { Datura innoxia }\end{array}$ & $\begin{array}{l}\text { R. stolonifer, A. alternate, } \\
\text { Botrytis cinerea }\end{array}$ & $\begin{array}{l}\text { Water soaked lesions which later showed } \\
\text { slimy wet rot }\end{array}$ \\
\hline Leaf rot & Hibiscus moschatus & P. butleri & Water soaked spots on the leaves \\
\hline Rhizome rot & Zingiber officinale & $\begin{array}{l}\text { Enterobacter cloacae, } \\
P . \text { aphanidermatum }\end{array}$ & $\begin{array}{l}\text { Yellowish brown to brown discolored tissue } \\
\text { of firm to spongy texture }\end{array}$ \\
\hline Root rot & $\begin{array}{l}\text { M. arvensis, Stevia } \\
\text { rebaudiana, C. forskohlii, } \\
\text { Asparagus officinalis }\end{array}$ & $\begin{array}{l}\text { R. bataticola, Sclerotinia rolfsii, } \\
\text { S. sclerotiorum, Fusarium } \\
\text { redolens }\end{array}$ & $\begin{array}{l}\text { Yellowing and dropping of leaves, with } \\
\text { wilting of plants and white cottony mycelia } \\
\text { growth at the collar region }\end{array}$ \\
\hline Stem rot & $\begin{array}{l}\text { C. roseus, } M \text {. arvensis, } \\
\text { Rosmarinus officinalis, } \\
\text { A. officinalis, } H . \text { moschatus }\end{array}$ & $\begin{array}{l}\text { Rhizopus stolonifer, } \\
\text { Sclerotinia sclerotiorum, } \\
\text { Botryodiplodia theobromae, } \\
\text { Phomopsis aspargi, P. parasitica, }\end{array}$ & $\begin{array}{l}\text { Pale green water soaked lesions. The fleshy } \\
\text { tissue becomes stingy and water exudes } \\
\text { rapidly. The tissue turns brownish with mild } \\
\text { odor. }\end{array}$ \\
\hline Soft rot & $\begin{array}{l}\text { P. somniferum, } C \text {. } \\
\text { borivilianum, } H \text {. muticus, } \\
\text { Aloe vera, } Z \text {. officinale }\end{array}$ & $\begin{array}{l}\text { Erwinia carotovora, } P \text {. } \\
\text { aphanidermatum, } \\
\text { Pseudomonas cichorii, } \\
\text { E. chrysanthemi }\end{array}$ & $\begin{array}{l}\text { Black streaks on the stem. The pitch regions } \\
\text { of the infected stems become sift, pulpy and } \\
\text { often produce dirty white, foul smelling } \\
\text { exudates. }\end{array}$ \\
\hline Wilt & $\begin{array}{l}P . \text { graveolens, } M . \text { arvensis, } \\
R . \text { serpentine, } W \text {. somnifera }\end{array}$ & Fusarium moniliformi, R. solani & $\begin{array}{l}\text { Withering and dropping of the plants, serve } \\
\text { wilting and cottony growth appear around } \\
\text { the main root. }\end{array}$ \\
\hline Damping off & P. somniferum & $\begin{array}{l}\text { Fusarium, Rhizoctonia, } \\
\text { Phytophthora, Sclerotinia, } \\
\text { Pythium spp. }\end{array}$ & $\begin{array}{l}\text { Infected seedlings turn yellow and then } \\
\text { collapse }\end{array}$ \\
\hline Root knot nematode & $\begin{array}{l}\text { Mentha spp., P. cablin, } \\
\text { O. basilicum, P. graveolens, } \\
\text { Hyoscynamus spp., } \\
\text { W. somnifera, Bacopa } \\
\text { monnieri, C. borivilianum, } \\
\text { Artemisia pallens }\end{array}$ & $\begin{array}{l}\text { Meloidogyne incognita, } \\
\text { M. javanica, M. hapla, } \\
\text { M. arvensis, Pratylenchus } \\
\text { brachyurus }\end{array}$ & $\begin{array}{l}\text { Galls are formed on infested root. Plants } \\
\text { are stunted, reduced tillering, yellowing, } \\
\text { premature drying of leaf tips and margins, } \\
\text { narrowing of leaf blades, delay in flowering, } \\
\text { immature fruit drop, excessive root } \\
\text { branching }\end{array}$ \\
\hline $\begin{array}{l}\text { Leaf curl/ Golden } \\
\text { yellow net }\end{array}$ & $\begin{array}{l}\text { M. viridis, Andrographis } \\
\text { paniculata }\end{array}$ & Begomovirus & $\begin{array}{l}\text { Growth stunting and curling of apical and } \\
\text { downward leaves. }\end{array}$ \\
\hline Mosaic diseases & $\begin{array}{l}\text { H. muticus, C. roseus, } \\
\text { R. serpentine, H. albus, } \\
\text { P. somniferum, Mentha } \\
\text { spp., A. paniculata }\end{array}$ & $\begin{array}{l}\text { Cucumber mosaic virus, } \\
\text { Tobacco mosaic virus, Potato } \\
\text { virus X, Tobacco rattle virus, } \\
\text { Carlavirus, Strawberry } \\
\text { latent ringspot virus, } \\
\text { Catharanthus yellow } \\
\text { mosaic virus }\end{array}$ & $\begin{array}{l}\text { Formation of mottle crinkle, mosaic patches } \\
\text { on the leaves, tiny leaves, stunting less } \\
\text { number of flower and malformed seeds }\end{array}$ \\
\hline $\begin{array}{l}\text { Phytoplasma } \\
\text { Diseases }\end{array}$ & $\begin{array}{l}\text { C. roseus, W. somnifera, } \\
\text { Foeniculum vulgare, } \\
\text { Phyllanthus amarus, } \\
\text { Matricaria chamomilla, } \\
\text { P. ovate, Portulaca } \\
\text { grandiflora }\end{array}$ & $\begin{array}{l}\text { Aster yellows, Peanut witches' } \\
\text { broom, Coconut lethal } \\
\text { yellowing, Elm yellows, Clover } \\
\text { proliferation, Ash yellows, } \\
\text { Luffa witches' broom, Pigeon } \\
\text { pea witches' broom, Bermuda } \\
\text { while leaf, Stolbur group }\end{array}$ & $\begin{array}{l}\text { Yellowing of leaves, general stunting, early } \\
\text { flowering, phyllody, witches' broom, } \\
\text { virescence, high levels of reproductive } \\
\text { failure, proliferation of axillary shoots, leaves } \\
\text { malformed, severe resetting and stunting }\end{array}$ \\
\hline
\end{tabular}

Andrographis paniculata, Hyoscyamus muticus, Catharanthus roseus, Rauvolfia serpentina, $H$. albus and Papaver somniferum (Khan et al., 2015; Postman et al., 2004). Plant viruses are the major pathogen of MAPs which produce a wide range of symptoms in plants, thereby causing huge losses in crop production all around the world. The symptoms expressed by the plant due to virus infection might be topical or systemic in nature and depend upon the strain of virus, plant variety and geocultural environment. The various kinds of symptoms include chlorosis, mosaic, discoloration of leaves and malformations (Tzanetakis et al., 2010).
The major plant viruses influencing MAPs growth are nematode-transmitted viruses (Arabis mosaic virus, Strawberry latent ring spot virus and Tobacco ring spot virus), aphid-transmitted viruses (Alfalfa mosaic virus, Cucumber mosaic virus and Mint vein banding associated virus), vitiviruses (Mint virus-2 and Peppermint stunt virus), thrips-transmitted viruses (Tospoviruses: Impatiens necrotic spot virus and Tomato spotted wilt virus), whitefly-transmitted viruses (Tomato leaf curl Pakistan virus), viruses with unknown vectors (Tobacco mosaic virus and Lychnis ringspot virus-mint). 
Like viruses, phytoplasmas are small (0.3-0.5 $\mu \mathrm{M}$ in size; 580-2,200 kb circular DNA genome), cell-walldeficient obligate parasites, related to the gram positive bacteria (Hogenhout et al., 2008). In the host plants, phytoplasma multiply and spread only in the phloem tissue of various organs. A number of studies have shown that in the phytoplasma-infected plant organs, the expression of genes concerned with primary and secondary metabolism, stress response, photosynthesis, cell growth, and development gets modified. This intervention in the host genome expression is primarily responsible for the phytoplasma disease symptoms. The most peculiar symptoms observed on these medicinal plants includes yellowing of leaves, general stunting, early flowering, phyllody (leaf-like flower organs), witches' broom (clustered branching), virescence (greening of flower petals), high levels of reproductive failure, proliferation of axillary shoots, leaves malformed, severe rosetting, stunting and death of entire plants (Bertaccini and Duduk, 2010; Christensen et al., 2005).

\section{Management}

Integrated management techniques are usually the best control measures for viral and phytoplasma pathogens. Soil drenching with carbendazim $(0.1 \%)$ or propiconazole $(0.1 \%)$ or dipping stem cuttings from disease free plants with carbendazim solution $(0.1 \%)$ is an effective treatment (Pandey, 2011; Reddy, 2014). Similarly, stem cuttings dipped in $0.1 \% P$. fluorescens at the time of planting and growing is an effective treatment (Boby and Bagyaraj, 2003). An intercrop of T. erecta in between the rows of several MAPs has been also found to be beneficial in controlling root-knot nematode problem by $66.7 \%$ and also decreases the incidence of Macrophomina phaseolina root rot disease up to 50 per cent (D'Addabbo et al., 2014) Further, drip irrigation should be used for minimizing the spread of pathogens from infected plants to healthy plants.

\section{Phytonematodes}

Plant parasitic nematodes constitute one of the most important groups of pathogenic organisms prevalent in and around the root playing a significant role in the plant growth and yield reductions. Undoubtedly, these nematodes are associated with most of the medicinal and aromatic plants and cause significant damage, but the magnitude of crop damage differ from plant to plants (Koshy et al., 2005). Primarily three species of plant parasitic nematodes i.e. Root-knot nematodes (Meloidogyne incognita and M. javanica), root lesion nematode (Pratylenchus thornei) and stunt nematode (Tylenchorhynchus vulgaris) affect cultivation of major medicinal and aromatic plants. The major crops which suffer root-knot nematode infestation are: Menthol mint, Henbanes, Basil, Opium poppy, Aswagandha, Sarpgandha, Coleus, Kinghao, Brahmi and Safed musli (Pandey, 1999; Pandey et al., 2016). Some models and techniques have been suggested to avoid the economic loss caused by plant parasitic nematode to medicinal and aromatic plants (Gupta et al., 2016).
The effective management of plant parasitic nematode through chemical nematicides for field use may not be available in the future. Consequently, it has become inevitable to manage this pathogen through nonchemical methods. Though, several non-chemical management tactics like fallow, flooding, changes in time of sowing/planting material, tillage practices, crop rotations, use of antagonistic crop, trap crop/cover crop, use of nematode free planting materials or seeds, solarization, organic amendment and biological control are available, efforts are directed towards the use of microbes to minimize the phytonematode population and to make soil more suppressive to nematode diseases (Pandey et al., 2016; Sikora, 1992). Different microbes have been exploited in this lab to reduce the population of phytonematodes below the economic threshold level (Reddy and Pandey, 2013) and could play a significant role either singly or can be integrated with other practices to develop integrated nematode management practices (INMP). Studies conducted at CSIR-CIMAP, Lucknow so far indicate that microbial agents may play a significant role in limiting phytonematode population (Saikia and Pandey, 2014). The results of the studies carried out on major medicinal plants like Artemisia annua, Artemisia pallens, Bacopa monnieri, Chlorophytum borivillianum, Hyoscyamus spp., Lavandula officinalis, Mentha arvensis, Rauvolfia serpentina, Withania somnifera etc. have proven the efficacy of microbial agents (Paecilomyces lilacinus, Glomus aggregatum, Trichoderma harzianum, Glomus fasciculatum, Glomus mosseae, Pseudomonas florescens, Bacillus subtilis, $B$. megaterium etc.) and organic farming in the management of nematodes and for sustainable growth and yield of medicinal and aromatic plants (Gupta et al., 2015a, b; Pandey et al., 1999; Singh et al., 2016b). Here the occurrence of various phytoparasitic nematodes affecting only three crops viz. mint, patchouli and Ashwagandha have been described in detail.

\section{Mint (Mentha spp.)}

Among different medicinal and aromatic plants mints come in the front line not only because of its pharmaceutical importance but also due to its many fold uses for the farmers. The farmer in tropical countries can grow it as a bonus crop as it fits well in the cropping system with other crops like paddy, wheat, potato, sugar cane, maize, okra, carrot, onion, spinach, pigeon pea, cowpea etc. This crop also generates significant employment and earns lot of foreign exchange. Different types of mints, which are commercially cultivated in tropical and subtropical countries, are: Menthol mint ( $M$. arvensis), Peppermint (Mentha piperita), Spearmint (Mentha spicata), Scotch spearmint (M. cardiaca), Bergamot mint (Mentha citrata) and Garden mint ( $M$. viridis).

\section{Nematodes of mints}

Nematodes have been identified as major pests of several mint species. The important nematodes which are affecting the yield are: Meloidogyne sp., Pratylenchus 
Table 2. Important phytonematodes affecting mint crops in India

\begin{tabular}{|c|c|}
\hline Plants / cultivars name & Major Phytonematode affecting the yield \\
\hline $\begin{array}{l}\text { Mentha arvensis var. MAS-1, Himalaya, HY-77, Siwalik, Kosi, } \\
\text { Gomti, Kalka }\end{array}$ & $\begin{array}{l}\text { Meloidogyne incognita, M. javanica, Pratylenchus thornei, } \\
\text { Tylenchorhynchus vulgaris, Longidorus pisi }\end{array}$ \\
\hline Mentha piperita cv. Kukrail & Pratylenchus thornei \\
\hline M. spicata cv. MSS-5, Arka, Neera, Neer, Kalka, MCAS-1 & Pratylenchus thornei,M. incognita \\
\hline M. cardiaca & M. incognita \\
\hline M. viridis & P. thornei , M.incognita \\
\hline
\end{tabular}

Table 3. Loss in total alkaloids in healthy and $M$. incognita race2 infested roots of Withania somnifera

\begin{tabular}{lc}
\hline Treatments & Alkaloids (\%) \\
\hline Healthy root & 0.32 \\
M. incognita severely infested roots & 0.11 \\
\hline
\end{tabular}

sp. and Tylenchorhynchus sp (Pandey and Patra, 2001). Several other phytonematodes are found to be associated with different mint species (Table 2).

Root-knot nematodes attack major medicinal and aromatic plants and are cosmopolitan in nature. Only two species i.e. Meloidogyne incognita and M. javanica are globally important for the menthol mint damage but the occurrence of $M$. incognita is more than $M$. javanica. Maximum R\&D work in nematodes of menthol mint has been carried out with M. incognita (Pandey, 1995, 2005; Pandey et al., 2011b).

\section{Symptoms of damage}

The major aerial symptoms in the fields of mint are stunting and chlorosis, which occur in patches. Root-knot infested suckers/ roots bear several galls of various sizes and most of the times eggs are easily visible on the root system (Fig. 1). The life cycle of $M$. incognita in menthol mint is completed in 28-30 days and occurs in menthol mint up to four generation under favourable condition. The race was identified as $M$. incognita race- 2 , which is predominant in Lucknow, Uttar Pradesh, India. As per records, the Meloidogyne species attack number of medicinal and aromatic plants. Meloidogyne juveniles/ eggs survive in the storage root/ suckers and these could be easily disseminated through suckers/roots, which are the main transplanting materials. Adhered soils with suckers and alternate weed host are also main source of the root-knot nematode inoculum.

\section{Management}

Meloidogyne species multiply well in sandy soil. Generally soil types where menthol mint is being cultivated is sandy loam therefore, damage caused by root-knot nematode in this region is several fold than in other regions. In one of the studies it has been reported that the infestation of root-knot nematode was more prevalent in sandy soil than clayey, which is less suitable for nematode multiplication (Fig. 1). As menthol mint is transplanted in January and this time period (February to April) is best suited for nematode development in menthol mint growing areas where nematode can complete three to four generations and build up their population up to the economic threshold level. Root-knot nematode ( $M$. incognita and $M$. javanica) caused $25-30 \%$ oil yield reduction in menthol mint. The quality of mint oil was also adversely affected due to nematode infection (Pandey, 2005). Management of phytonematodes is one of the most important prerequisite to minimize injury to crop plants. Nematode injury provides entry to a wide variety of plant-pathogenic fungi and bacteria, which may cause other serious diseases. These microbial infections may result in greater losses than the damage from nematodes alone. Preplant treatment for the nematode control is essentially important because once a plant is parasitized it is really difficult to cure. The most sustainable approach to nematode control involves the integration of several strategies, including the use of pesticides, organic materials, bio-agents, resistant/ tolerant plant varieties, cultural practices etc. To manage root-knot nematode in menthol mint through ecofriendly way is a difficult task because of endoparasitic nature of pathogen (Pandey et al., 2015).

Several germplasm available with CSIR-CIMAP, Lucknow gene bank were screened for their resistance to Meloidogyne incognita (Pandey and Patra, 2001). Most of the 25 accessions screened for $M$. incognita infection,
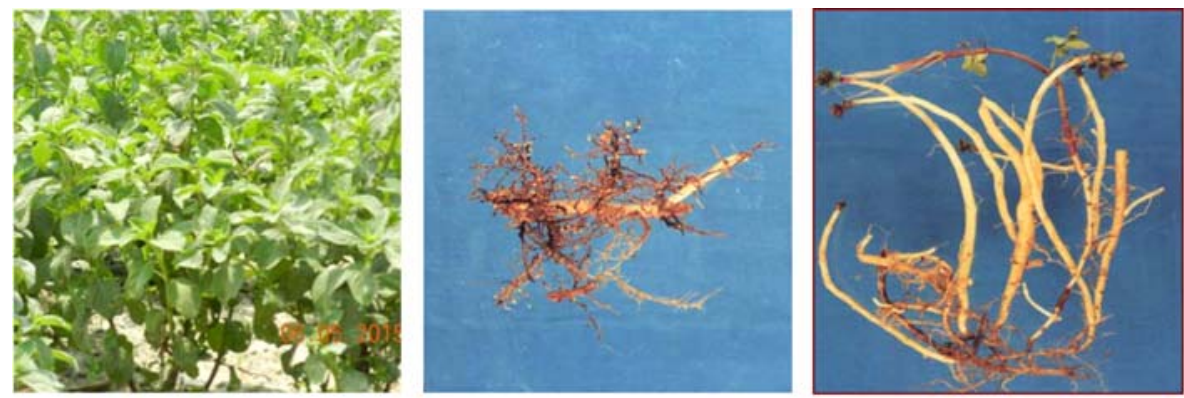

Fig. 1. Menthol mint plant and its root-knot nematode (Meloidogyne incognita) infested suckers 
showed susceptible reaction to nematode infection of varying degree. Highest root-knot infection was rated on Siwalik, SS-18 and Himalaya. Comparatively moderate reaction was found on SS-11, SS-27, Gomti, Kosi, M. cardiaca and $\mathrm{MAH}-1$ respectively. The lowest infection level was found on SS-5, SS-5-4, Kalka and SS-20. On the other hand moderate to high degree of resistance was noticed on SS-1-4, SS-2-7, SS-15, SS-26, SS-36, Mentha piperita cv. Kukrail, M. spicata cv. Neera, M. spicata cv. Arka, M. citrata cv. Kiran, M. gracilis and $M$. viridis respectively. These can be further exploited for future breeding programme for developing root-knot resistant mint genotypes. Experiments conducted in our experimental farm suggest that inclusion of some non host like mustard and wheat crop help to a great extent in reducing the population of Meloidogyne spp. and its occurrence and severity on menthol mint crop. The late transplanted mint technology developed at CSIR-Central Institute of Medicinal and Aromatic Plants, Lucknow which allows farmers to have non host crop like wheat, mustard etc. has greatly benefited the farmer in fighting root-knot nematode menace to some extent. Further the higher temperature prevailing during the transplanted cropping season (April-July) also checks the nematode population buildup and infection of menthol mint crop.

\section{Patchouli (Pogostemon cablin syn. patchouli)}

Root-knot nematode (M. incognita, M. javanica, M. hapla) has become a major constraint for the successful cultivation of patchouli in different parts of India.

\section{Symptoms of damage}

Root-knot infested plants are weak and grow slowly. Heavy galling on root system with root knot nematode on patchouli results in stunting, wilting, defoliation and chlorosis of the plant. Sometimes root galls are very small or the surrounding galls coalesce to form large one up to $2-5 \mathrm{~cm}$ large even more (Fig. 2). Infection of root-knot nematodes occurs when plants are in their early stage of development. Bhau et al. (2016) confirmed the destructive effects of $M$. incognita infestation as an initial population of juveniles per $1500 \mathrm{~J} 2$ /plant was reported to inflict serious losses in Patchouli yields. Bhau et al. (2016) confirmed the destructive effects of $M$. incognita infestation as an initial population of juveniles per 1500 $\mathrm{J} 2 /$ plant was reported to inflict serious losses in Patchouli yields.
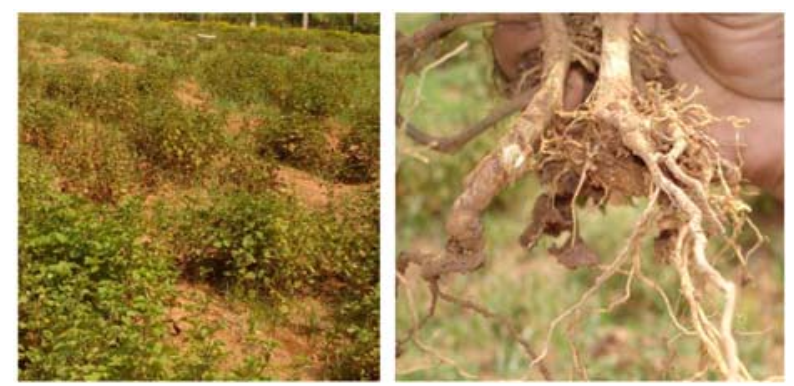

Fig. 2. Root-knot nematode infested field of patchouli and its root system with root-knots

\section{Management}

A large number of experiments were conducted to manage phytoparasitic nematode on patchouli. Krishnaprasad and Reddy $(1979,1984)$ used AldicarbSulfone, Aldicarb-Fensulphothion, Carbofuran, Cyerolan AC-92 and AC-100 @ 3.6 and 10kg a.i./ ha as pre and post inoculation treatment. Good control of $M$. incognita on patchouli was obtained by these chemicals. Sarwar et al. (1982) also conducted some experiment with fensulphothion, carbofuran, aldicarb, nemagon, metham sodium, fphenamiphos to control root-knot nematode $M$. incognita on patchouli. Carbofuran was one of the most effective chemicals for $M$. incognita control. In another experiment effect of different oil seed cakes such as neem, pongamia and castor cake on plant growth and nematode population development was studied. Neem oil seed cake @ 4 tonnes/ha proved better than other oil seed cakes for increasing growth and yield of the crop and reducing the $M$. incognita population. Mucuna purita as rotational crop with patchouli was found to be effective for reducing root-knot nematode population. Summer fallowing also proved to be a good method for reducing M. incognita population below threshold level. Kumar and Nanjan (1984) applied aldicarb, carbofuran or phorate @ 2-3 kg a.i./ha to manage the Helicotylenchus dihystera on P. patchouli. Significant control of spiral nematode on this crop was observed and increase yield of crop was detected in all the treatment. Simarlarly large number of bioagents and pesticide tested for their positive impact on oil yield and root-knot development in patchouli (Pandey et al., 2009).

\section{Ashwagandha}

Root-knot disease of ashwagandha caused by the rootknot nematode Meloidogyne incognita (Kofoid and White) Chitwood, is very widespread affecting more than $80 \%$ plants in India. Race identification was done using host differential test and was identified as race-2 (Pandey and Kalra, 2003). Nematodes were multiplied on roots of tomato and pathogenicity of $M$. incognita was confirmed on 10-day-old potted plant of $W$. somnifera. Large numbers of other phytoparasitic nematodes were found to be associated in root rhizosphere of Ashwagandha.

\section{Symptoms of damage}

The nematode infected plants typically show chlorosis, stunted growth, less branched with fewer and smaller leaves and poor response to fertilizer and irrigation. Such symptoms usually are not noticeable until severe damage to root system has been done by the nematodes. Roots of such plant were severely galled. When stem touches the soil it was also found to be infested with root-knot nematode $M$. incognita (Fig. 3). It was also noticed that root-knot nematode infected plants are more likely to be killed early with adverse effect of environment than healthy noninfested plants.

\section{Management}

Management studies were carried out (Pandey and Kalra, 2003) through the use of different organic materials and 

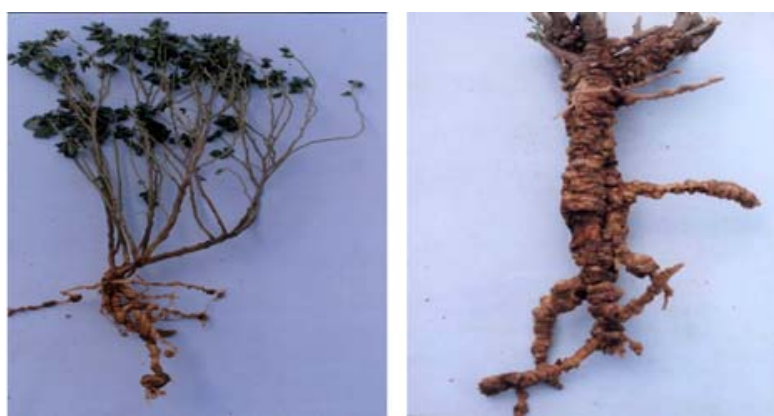

Fig. 3. Root knot nematode ( $M$. incognita race -2) infested plants and roots of $W$. somnifera

bioagent on growth/ yield of $W$. somnifera and nematode reproduction. In the experimentation neem compound, Artemisia annua marc, Mentha and M. koenigii distillates were found highly useful to suppress the root-knot development and $M$. incognita population on $W$. somnifera. Bio-agents however were found less effective as compared to organic materials on $W$. somnifera; may be due to host reactions towards the bio-agents. Integration of Vermicompost with Trichoderma harzianum and Mentha distillates with G. aggregatum were found nematode suppressive and enhanced the growth of $W$. somnifera significantly. It was concluded that neem compound, A. annua marc, vermicompost and their integration with bio-agents can be an important way for nematode management, which could pave the way in future for integrated nematode management programme on agricultural and commercial crops. Uses of essential oils were also found to be nematode inhibitory in Ashwagandha (Pandey et al., 2011a). Use of bio-organics (organic materials, bioagent) is a potential alternative to the environment detrimental chemical nematicides, which are generally used to restrict nematode infestation in agricultural crops. Use of different bio-organics viz. farm yard manures (Fym), cow urine, neem cake, vermicompost, T. harzianum, Paecilomyces lilacinus separately and in dual combinations against root-knot disease of $W$. somnifera and successful management of root-knot nematode on this crop were achieved (Saikia et al., 2013, Singh et al., 2016a; Tiwari et al., 2016; Gupta et al., 2016). Similarly large number of medicinal and aromatic plants were also affected by variety of plant parasitic nematode and have severe impact on production of plant secondary metabolites (Gupta and Pandey, 2015; Singh et al., 2016b; Gupta et al., 2017a, b; Tiwari et al., 2017). My lab has recently published a few research papers on MAPs which may be highly beneficial to future researchers in field of medicinal and aromatic plants (https://scholar.google.co.in/citations).

\section{Future directions}

Despite the exceptional progress in the production of synthetic compounds during the last two decades, plants continue to be the main source of important drugs. Biotic invasions on such "wonder plants" in the form of several pathogens however, are a major hindrance not only on total production but also on the quality of the produce.
Further, with the changing climatic conditions resurgence of diseases is expected to shoot up. Diseases cannot be completely eradicated but development of new systems for detection, identification and monitoring can play a vital role in effective disease management in medicinal and aromatic plants. Also, disease management strategies should focus specifically on the eco-friendly and integrated disease management practices so as to protect our "treasure trove".

\section{ACKNOWLEDGEMENTS}

Author is grateful to Prof. Anil K. Tripathi, Director CSIRCIMAP, Lucknow for his kind help and encouragements and also to all his students of Microbial Technology and Nematology Department, CSIR-CIMAP for their kind help in all the ways during preparation of this manuscript.

\section{REFERENCES}

Bertaccini A and Duduk B (2010). Phytoplasma and phytoplasma diseases: a review of recent research. Phytopathol. Mediterranea 48: 355-378.

Bhandari S, Harsh NSK, Sharma AK, Mao LP and Thakur S (2014). A Database of Diseases of Medicinal Plants in Uttarakhand. Indian Forester 140: 518-527.

Bhau BS, Borah B, Ahmad R, Phukon P, Gogoi B, Sarmah DK, Lal M and Wann SB (2016). Influence of root-knot nematode infestation on antioxidant enzymes, chlorophyll contentand growth in Pogostemon cablin (Balanco) benth. Indian J. Exp. Biol. 54: 254-261.

Boby VU and Bagyaraj DJ (2003). Biological control of root-rot of Coleus forskohlii Briq. using microbial inoculants. World J. Microbiol. Biotechnol. 19: 175-180.

Christensen NM, Axelsen KB, Nicolaisen M and Schulz A (2005). Phytoplasmas and their interactions with hosts. Trends Plant Sci. 10: 526-535.

D'Addabbo T, Laquale S, Lovelli S, Candido V and Avato P (2014). Biocide plants as a sustainable tool for the control of pests and pathogens in vegetable cropping systems. Italian J. Agro. 9: 137-145.

Elad $Y$ and Pertot I (2014). Climate Change Impacts on Plant Pathogens and Plant Diseases. J. Crop Impro. 28: 99-139.

Gupta R and Pandey R (2015). Microbial interference ameliorates essential oil yield and diminishes root-knot infestation in sweet basil under field conditions. Biocontrol Sci. Technol. 25: 1165-1179.

Gupta R, Tiwari S, Saikia Shilpi K, Shukla V, Singh R, Singh SP, Kumar PV Ajay and Pandey R (2015a). Exploitation of microbes for enhancing bacoside content and reduction of Meloidogyne incognita infestation in Bacopa monnieri L. Protoplasma 252: 53-61.

Gupta R, Saikia SK and Pandey R (2015b). Bioconsortia augments antioxidant and yield in Matricaria recutita $\mathrm{L}$. against Meloidogyne incognita (Kofoid and White) Chitwood Infestation. Proceed. Nat. Acad. Sci, India Sec. B: Biol. Sci. doi: 10.1007/s40011-015-0621-y.

Gupta R, Singh A, Srivastava M, Gupta MM and Pandey R (2016). Augmentation of systemic resistance and secondary metabolites by chitinolytic microbes in Withania somnifera against Meloidogyne incognita. Biocontrol Sci. Technol. 26: 1626-1642.

Gupta R, Singh A and Pandey R (2017a). Chitinolytic microbes confer Meloidogyne incognita resistance and augment 
secondary metabolites in Bacopa monnieri (L.) Pennell. Arch. Phytopathol. Plant Prot. doi: 10.1080/ 03235408.2017.1285522.

Gupta R, Singh A, Srivastava M, Singh V, Gupta MM and Pandey $R$ (2017b). Microbial modulation of bacoside A biosynthetic pathway and systemic defense mechanism in Bacopa monnieri under Meloidogyne incognita stress. Sci. Reports, Nature Publishing 7: 41867. doi: 10.1038/srep41867.

Hogenhout SA, Oshima K, Ammar ED, Kakizawa S, Kingdom $\mathrm{HN}$ and Namba S (2008). Phytoplasmas: bacteria that manipulate plants and insects. Mol. Plant Pathol. 9: 403423.

Khan A, Saeed ST and Samad A (2015). New Record of Catharanthus Yellow Mosaic Virus and a Betasatellite Associated with Lethal Leaf Yellowing of Kalmegh (Andrographis paniculata) in Northern India. Plant Dis. 99: 292-2.

Koshy PK, Pandey R and Eapen SJ (2005). Nematode Parasites of Spices, Condiments and Medicinal Plants Plant Parasitic Nematodes in Subtropical and Tropical Agriculture $2^{\text {nd }}$ Edition (Eds. Luc M, ORSTOM, France, R. A. Sikora, University of Bonn, Germany, J. Bridge, CABI, Bioscience, Egham, Surrey, U.K.): 751-791.

Krishnaprasad PR and Reddy DDR (1979). Study on the rootknot nematode infecting patchouli (Pogostemon cablin Benth.). Mysore J. Agric. Sci. 13: 367-368.

Krishnaprasad PR and Reddy DDR (1984). Pathogenicity and analysis of crop losses in patchouli due to Meloidogyne incognita. Ind. J. Nematol. 14: 36-38.

Kumar S and Nanjan K (1984). Control of spiral nematode in patchouli. Fungicide \& nematicide tests. Phytopathol. 39: 93.

Pandey R and Saikia K Shilpi (2012). Climate Change Vs Phytonematodes. In National Conference on Managing Threatening Diseases of Horticultural, Medicinal, Aromatic and Field Crops in Relation to Changing Climatic Situation in Zonal Meeting, Indian Phytopathological Society (MEZ) at Indian Institute of Sugarcane Research, Lucknow on Nov, 3-5, 2012: 50-55.

Pandey R (1995). Application of oil seed cake, pesticides and dry leaf matter on the reproduction potential of Meloidogyne incognita and yield of Japanese mint. Indian J. Nematol. 25: 1213.

Pandey R (2011). Nematicidal activities of natural lignans and derivatives from milky thistle against Meloidogyne incognita. Indian Phytopath. 64: 182-185.

Pandey R and Kalra A (2003). Root-knot disease of Ashwagandha, Withania somnifera and its ecofriendly and cost effective management. J. Mycol. Plant Pathol. 33: 240245.

Pandey R and Patra NK (2001). Screening mint (Mentha spp.) accessions against root-knot nematode infection. J. Spices Aromat. Crops 10: 55-56

Pandey R (2005). Field application of bio-organics in the management of Meloidogyne incognita in Mentha arvensis. Nematol. Medit. 33: 51-54.

Pandey R, Kalra A and Gupta ML (2009). Evaluation of bioagents and pesticide on root-knot nematode development and oil yield of patchouli. Arch. Phytopathol. Plant Protection. 42: 419-423.

Pandey R, Kumar S, Gupta ML and Singh HN (1999). Rootknot disease of Opium poppy a new disease record. Indian Phytopath. 52: 78.
Pandey R, Mishra AK, Tiwari S and Kalra A (2011a). Nematode inhibiting organic materials and a strain of Trichoderma harzianum effectively manages Meloidogyne incognita in Withania somnifera fields. Biocontrol Sci. Tech. 21: 14951499.

Pandey R, Mishra AK, Tiwari S, Singh HN and Kalra A (2011b). Enhanced tolerance of Mentha arvensis against Meloidogyne incognita (Kofoid and White) Chitwood through mutualistic endophytes and PGPRs. J. Plant Interact. 6: 247-253.

Pandey R, Gupta ML, Singh HB and Kumar S (1999). Interaction potentialities of Vesicular-arbuscular mycorrhizal fungi with root knot nematode, Meloidogyne incognita on black henbane. Bioresource Techn. 69: 275-278.

Pandey R, Gupta R and Singh A (2016). Microbes: A functional mediator for phytonematode management in medicinal plants. In conservation, cultivation, diseases and therapeutic inmportance of medicinal and aromatic plants Eds. Chourasia HK and Roy AK, TMBU, Bhagalpur): 2141.

Pandey R, Zaim M and Saikia K Shilpi (2015). Effective management of biotic grievances in medicinal and aromatic plants in Plant Disease Biocontrol Management (Eds. Trivedi PC): 37-74.

Paramasivan M, Mohan S and Muthukrishnan N (2007). Management of Coleus dry root rot pathogen Macrphhomina phaseolina by fungal and bacterial antagonist. Indian J. Plant Protect. 35: 133-135.

Pliego C, Kamilova F and Lugtenberg B (2011). Plant growthpromoting bacteria: fundamentals and exploitation. In Bacteria in Agrobiology: Crop Ecosystems (pp. 295-343). Springer Berlin Heidelberg.

Postman JD, Tzanetakis IE and Martin RR (2004). First report of Strawberry latent ring spot virus in a Mentha sp. from North America. Plant Dis. 88: 907-907.

Ramappa Parashurama T and Shivanna MB (2013). Fungal foliar diseases of Rauwolfia serpentina in wild, its seasonal occurrence, seed transmission and disease management. Arch. Phytopathol. Plant Protect. 46: 1609-1621.

Reddy PP and Pandey R (2013). "Plant Protection in Medicinal and Aromatic Plants" $488 \mathrm{pp}$. Published by Studium Press LLC, Houston TX 77-72 USA.

Reddy PP (2014). Medicinal Crops. In Plant Growth Promoting Rhizobacteria for Horticultural Crop Protection (pp. 279293). Springer India.

Saikia SK, Tiwari S and Pandey R (2013). Rhizospheric biological weapons for growth enhancement and Meloidogyne incognita management in Withania somnifera cv. Poshita. Biol. Control 65: 225-234.

Saikia SK and Pandey R (2014). Rhizospheric Microflora Escalating Aroma Constituents and Yield Attributes in Ocimum tenuiflorum (L.) cv. CIM-Ayu. Adv. Agri. 1-7. http:/ /dx.doi.org/10.1155/2014/621912.

Sarwar M, Parameswaren TN, Shanamugham C and Narayana MR (1982). Appraisal of patchouli in India, root-knot problem and control. Indian Perfumer 26: 117-121.

Schippmann U, Leaman DJ and Cunningham AB (2002). Impact of cultivation and gathering of medicinal plants on biodiversity: global trends and issues. Biodiversity and the ecosystem approach in agriculture, forestry and fisheries. Inter-Department Working Group on Biology Diversity for Food and Agriculture, FAO, Rome, Italy.

Sikora RA (1992). Management of the antagonistic potential in agricultural ecosystems for the biological control of plant parasitic nematodes. Ann. Rev. Phytopathol. 30: 245-270. 
Singh A, Gupta R, Srivastava M, Gupta MM and Pandey R (2016a). Microbial secondary metabolites ameliorate growth, in planta contents and lignification in Withania somnifera (L.) Dunal. Physiol. Mol. Biol. Plants 22: 253260.

Singh A, Gupta R, Saikia SK, Pant A and Pandey R (2016b). Diseases of medicinal and aromatic plants, their biological impact and management. Plant Genet. Res. 14: 370-373.

Thaung MM (2008). Pathologic and taxonomic analysis of leaf spot and tar spot diseases in a tropical dry to wet monsoon ecosystem of lowland Burma. Australas. Plant Pathol. 37: 180-197.
Tiwari S, Pandey S, Chauhan PS and Pandey R (2017). Biocontrol agents in co-inoculation manages root knot nematode, Meloidogyne incognita (Kofoid \& White) Chitwood, and enhances essential oil content in Ocimum basilicum L. Ind. Crops Prod. 97: 292-301.

Tiwari S, Saikia SK, Singh R, Singh SP and Pandey R (2016). Native microbial inoculants for the management of Meloidogyne incognita in Withania Somnifera cv. Poshita. Proceed. Nat. Acad. Sci., India Sec. B: Biol. Sci. 86: 55-63.

Tzanetakis IE, Postman JD, Samad A and Martin RR (2010). Mint viruses: Beauty, stealth, and disease. Plant Dis. 94: 4-12. 